\title{
Development of Optimal Management Strategies for the Interception System Using River Water Quality Modeling
}

\author{
Chen-Yao $\mathrm{Ma}^{1}$, Yi-Chu Huang ${ }^{1, \mathrm{a}}$ and Chih-Ming $\mathrm{Kao}^{2}$ \\ ${ }^{1}$ Department of Environmental Science and Engineering, National Pingtung University of Science and Technology, Xuefu Road, Laojiao \\ Village, Neipu Township, Pingtung County 91201, Taiwan \\ ${ }^{2}$ Institute of Environmental Engineering, National Sun Yat-sen University, No.70, Lianhai Road, Kaohsiung City 80424, Taiwan
}

\begin{abstract}
This study adopted the water quality model [Water Quality Analysis Simulation Program (WASP)] to simulate and evaluate the impacts of the opening and closure of an interception system at the tributary of Love River on mainstream water quality. The gates were opened respectively for 4,12 , and 24 hours to assess the impact on biochemical oxygen demand (BOD) and ammonia nitrogen $\left(\mathrm{NH}_{3}-\mathrm{N}\right)$ in the water bodies of Love River. The WASP model was used to evaluate the self-purification capacity of the river. According to the results of the model estimation, it takes 5 days for $\mathrm{NH}_{3}-\mathrm{N}$ and $\mathrm{BOD}$ in the water bodies of Love River to return to normal and for the water to restore its original water quality after the closure of the Baozhu Ditch gate. Results of this study can be used as a reference for Love River watershed management, and the WASP modeling can be applied for decision makers to develop appropriate management strategies of the interception system.
\end{abstract}

\section{INTRODUCTION}

A large number of research studiees in the past applied a model to simulate water quality $[1,2,3,4]$. But water quality models were seldom used to evaluate the impacts of the opening and closure of gates to a river in the past $[5,6]$. Therefore, this study selected the WASP water quality model to evaluate the quality benefits and impacts of the opening and closure of an interception system on river water quality, simulated the water quality of the river at the closure of the interception system, and simulated the impact of the opening time of gates on water quality. The results of this study will be available as a reference for watershed management.

\section{RESEARCH METHODS}

\subsection{Hydrology and water quality data collection}

The water quality monitoring data of various monitoring stations from 2011 to 2014 published online by EPB, Kaohsiung City Government were collected; model calibration and validation were conducted based on the drainage load and mainstream water quality from an onsite investigation of the study; and a simulation and estimation of the water quality of the river watershed were carried out $[7,8,9]$. Each monitoring station of EPB includes a total of 10 monitoring sites.

\subsection{WASP model construction}

This study employed WASP for water quality model analysis. The range of water quality simulation of Love River was constructed from the upstream boundary, Hougang Bridge (10.1 km from the marine outfall), to the downstream boundary, Kaohsiung Bridge (the marine outfall), with a total length of $10.1 \mathrm{~km}$. A total of 21 grid segments was built in this range, the length of each grid segment was 500 meters. Use steady-state mass transfer simulations and conductivity verification.

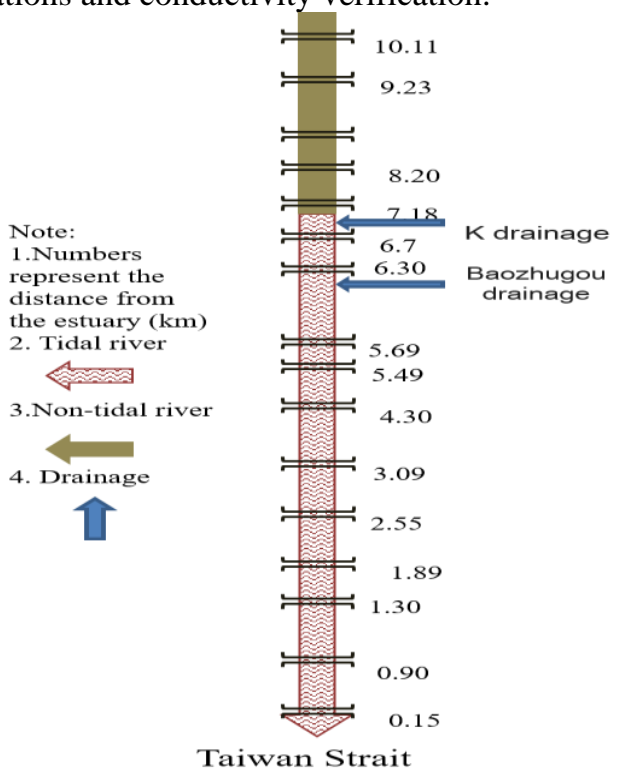

Figure 2.1 Water quality simulation grid and tributary drainage position of Love River.

${ }^{a}$ Corresponding author : ych@ mail.npust.edu.tw 


\subsection{Simulation program}

In this study, the WASP water quality model was used to simulate the impact of the closure of gates on Love River and evaluate programs with different opening times. To explore the impact of Baozhu Ditch drainage on the water quality of Love River, and provide self-purification capacity of Love River for related units. This study will take into account the following situations:

(1) Open the gates in sunny days to simulate the impact of pollutant loads on the water quality of Love River for 4, 12, and 24 hours after the opening of gates to determine the appropriate timing during sunny days.

(2) Simulate the change of water quality of Love River after the opening of gates (4 hours) to evaluate its selfpurification capacity.

\section{Results and Discussion}

\subsection{Water quality model verification and BOD,} and $\mathrm{NH}_{3}-\mathrm{N}$ simulation results

The simulated water quality measures included BOD, $\mathrm{DO}$, and $\mathrm{NH}_{3}-\mathrm{N}$. The simulated and measured results of $\mathrm{BOD}$, DO, and $\mathrm{NH}_{3}-\mathrm{N}$ with river distance changes simulated based on the validation results of Love River from 2011 to 2014 (Figure 3.1, and Figure 3.2) showed that at a distance of $5.49-8.50 \mathrm{~km}$ from the downstream boundary (Baozhu Ditch draining water station to Dingxin Bridge smiling gravel inter-treatment system), there was a gap between the simulated and measured values of BOD. Overall, the simulated and measured values of $\mathrm{BOD}$, and $\mathrm{NH}_{3}-\mathrm{N}$ both have the same trend.
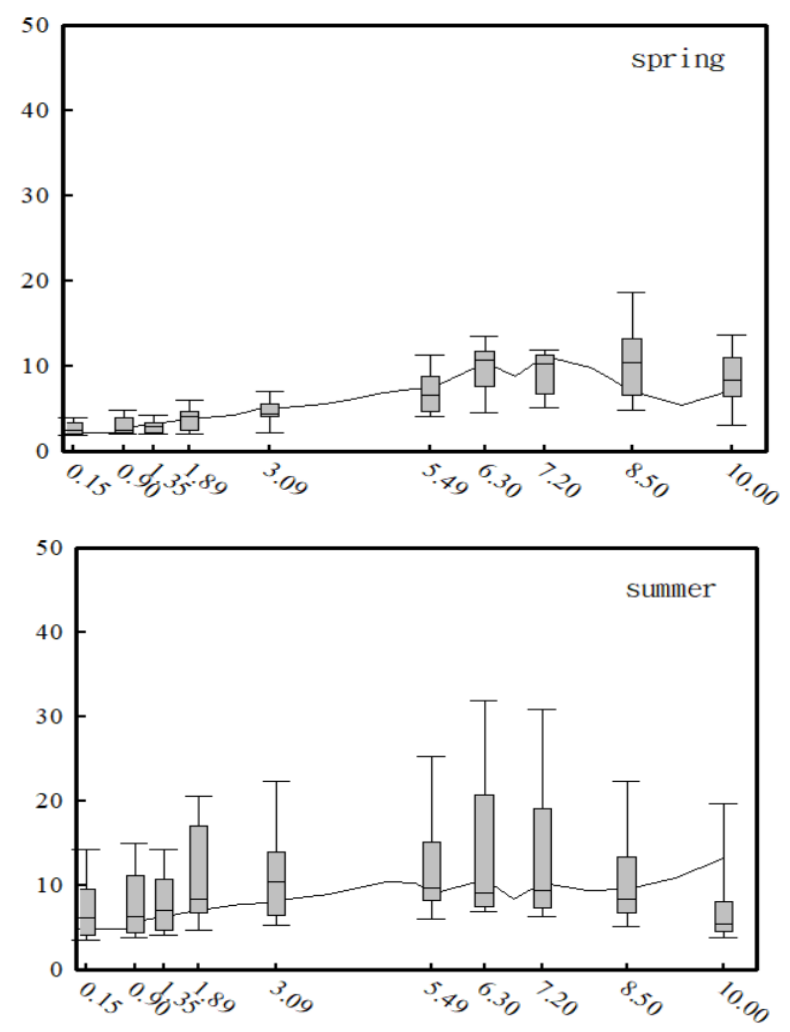
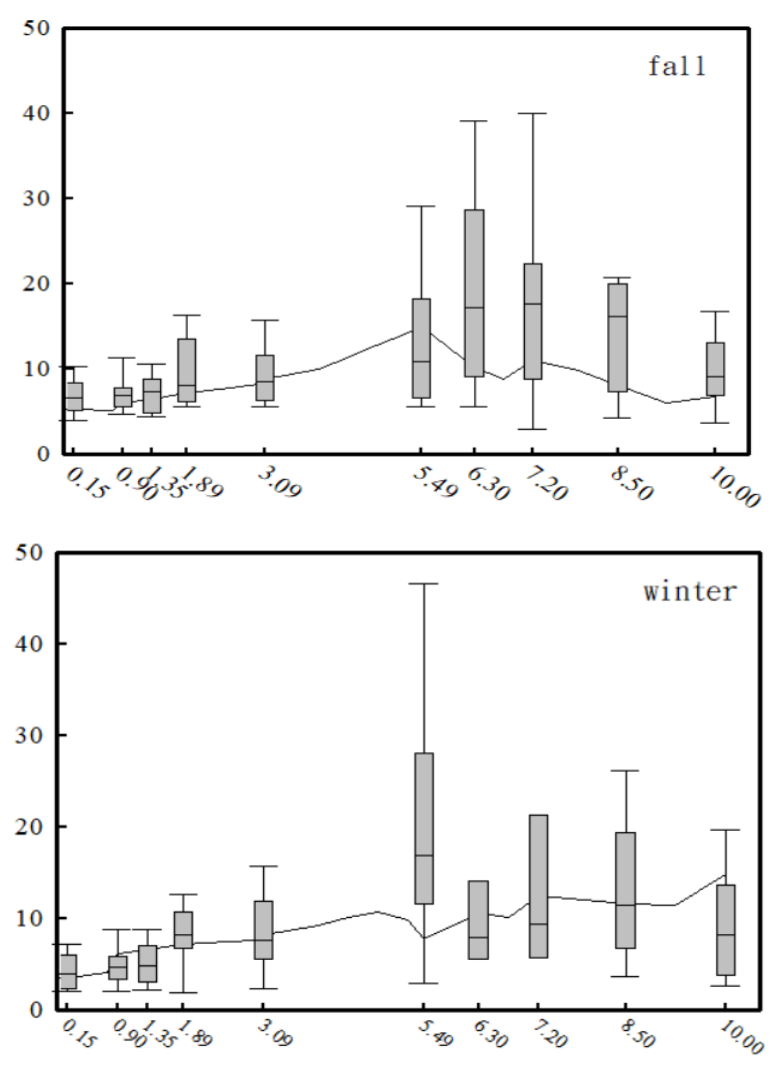

Figure 3.1 BOD simulation values for the four seasons in Love River (Y axis: Concentration, unit: $\mathrm{mg} / \mathrm{L} ; \mathrm{X}$ axis: Distance from marine outfall, unit: $\mathrm{km}$ ).
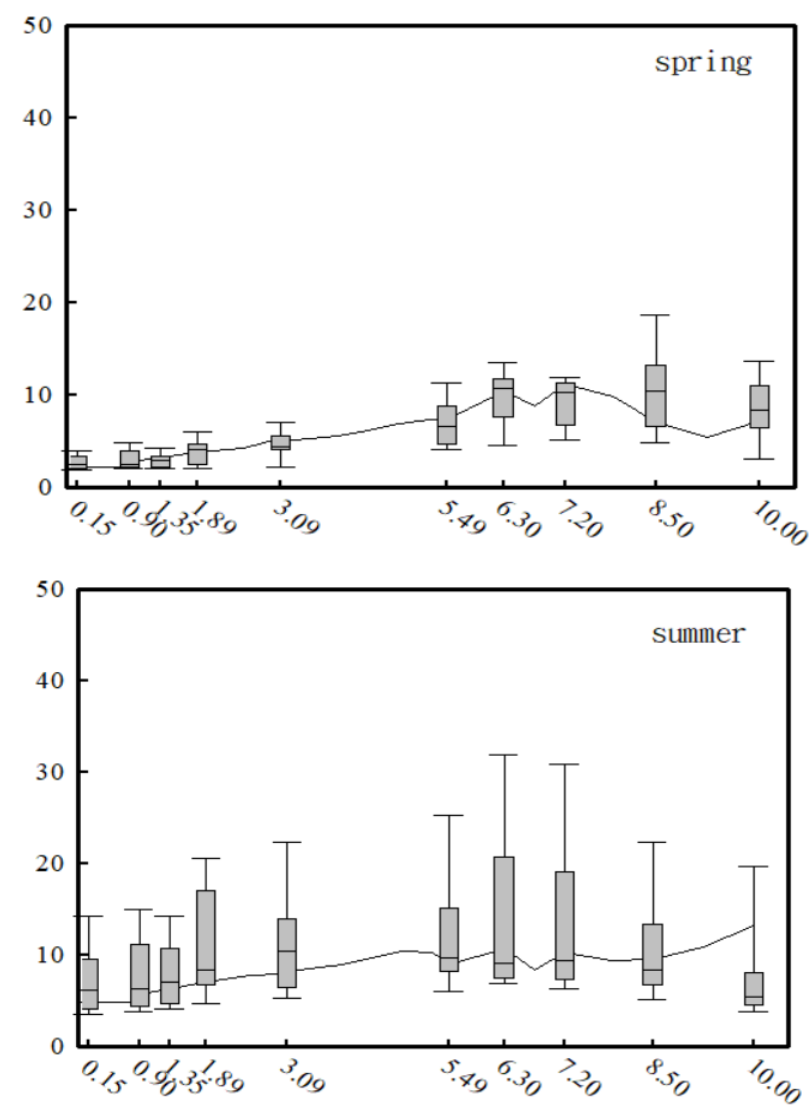

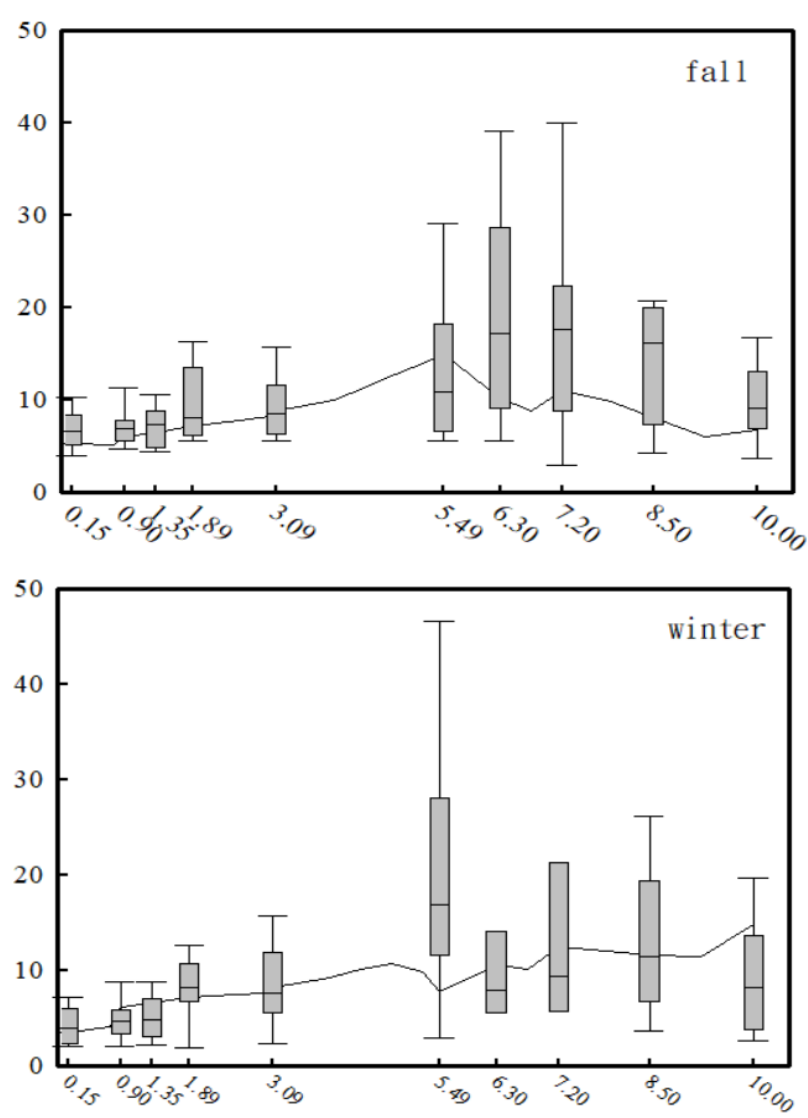

Figure 3.2 $\mathrm{NH}_{3}-\mathrm{N}$ simulated values for the four seasons in Love River (Y axis: Concentration, unit: $\mathrm{mg} / \mathrm{L}$; $\mathrm{X}$ axis: Distance from marine outfall, unit: $\mathrm{km}$ ).

\subsection{Impact of the opening and closure of the gates of Baozhu Ditch and K-Trunk on the water quality of Love River}

\subsubsection{Biochemical oxygen demand simulation results}

The simulation results of K-trough and Baozhugou are shown in Fig. 3.3 and Fig. 3.4. Fig. 3.3 shows that the measured maximum BOD concentration over the years (2011-2014) coincided with the simulated concentration of K-gate opening for 4 hours. Figure 3.4 shows that the highest measured concentration of BOD corresponds to the simulated concentration of the opening of the Baozhu Ditch gate for 4 hours. It was confirmed that the water adjustment time of Baozhugou was mostly within 4 hours of the opening of the gate.

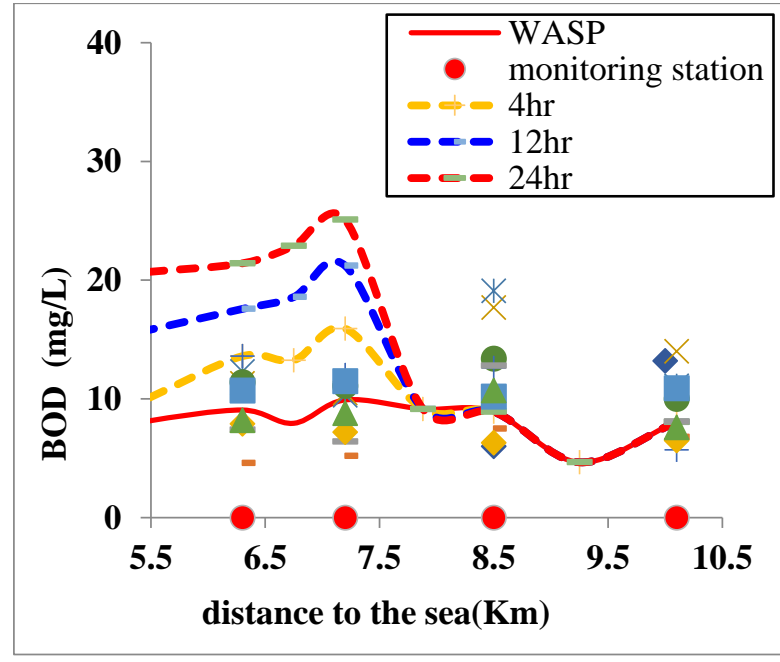

Figure 3.3 Impact of opening the gate of K-Trunk on BOD through WASP stimulation.

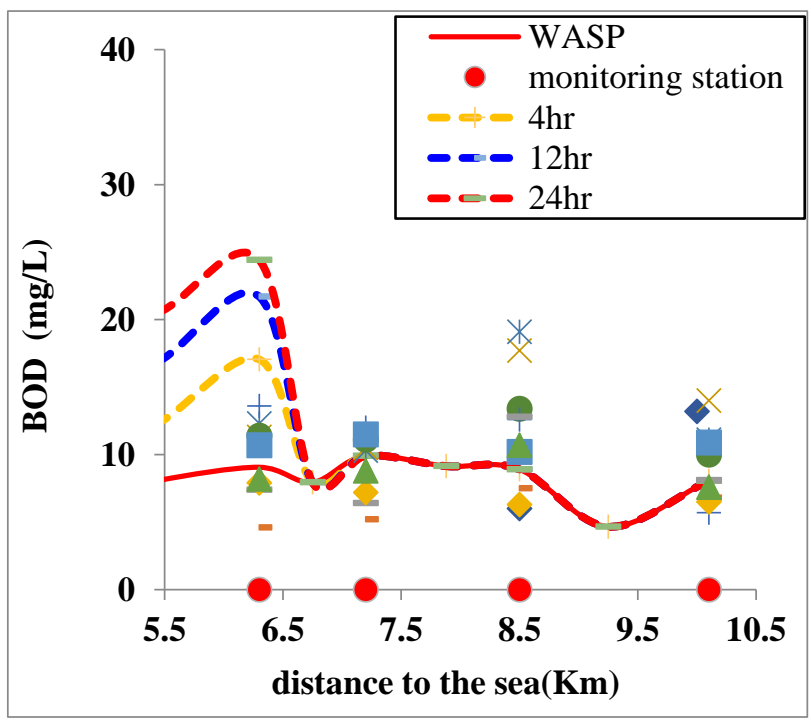

Figure 3.4 Impact of opening the gate of Baozhu Ditch on BOD through WASP stimulation.

\subsubsection{Ammonia nitrogen simulation results}

The simulation results of K-trunk and Baozhugou are shown in Figure 3.5 and Figure 3.6. Fig. 3.5 shows that the measured maximum $\mathrm{NH}_{3}-\mathrm{N}$ concentration over the years (2011-2014) coincides with the simulated concentration of K-trunk gate opening for 24 hours. However, as shown in Figure 3.6, the measured $\mathrm{NH}_{3}-\mathrm{N}$ concentration coincides with the simulated concentration of the Baozhu Ditch gate opening for 4 hours. However, the $\mathrm{NH}_{3}-\mathrm{N}$ monitoring values over the years are concentrated and consistent with the opening of the Baozhugou sluice gate within 4 hours. The simulated value shows that the water volume adjustment time of Baozhugou is mostly within 4 hours of opening the gate. 


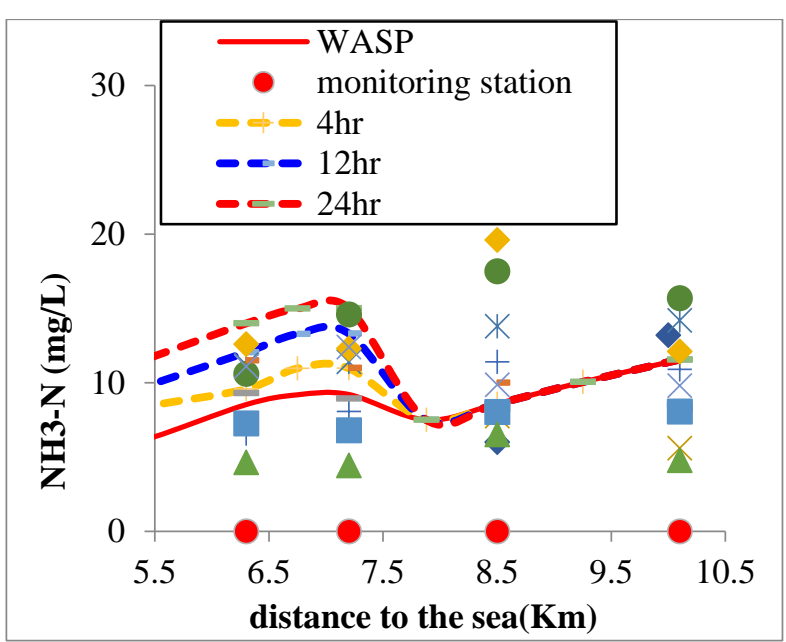

Figure 3.5 Impact of opening the gate of K-Trunk on $\mathrm{NH}_{3}-\mathrm{N}$ through WASP stimulation.

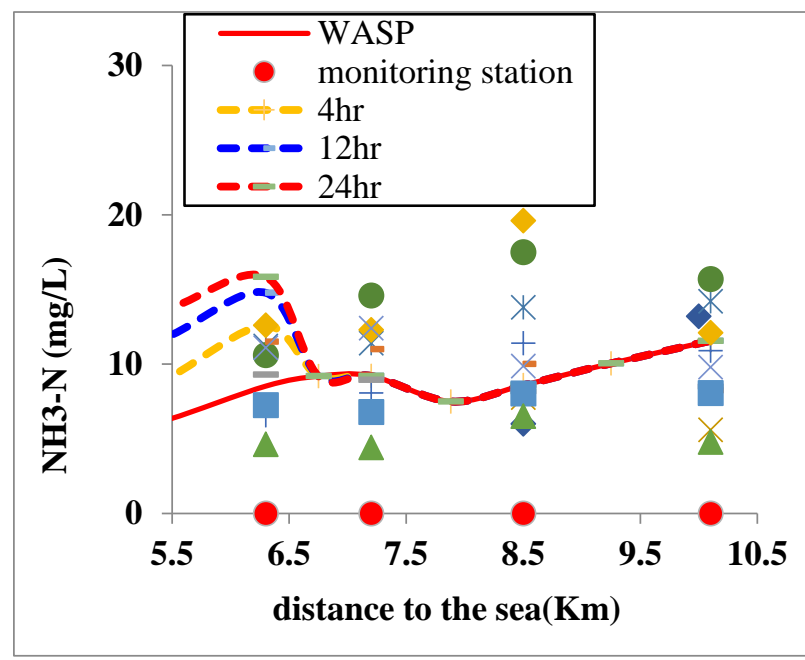

Figure 3.6 Impact of opening the gate of Baozhu Ditch on $\mathrm{NH}_{3}-\mathrm{N}$ through WASP stimulation.

\subsection{Self-purification capacity simulation of Love River}

Table 3.3 shows the change of $\mathrm{NH}_{3}-\mathrm{N}$ concentration in Love River after 4 hours of opening and closure of the Baozhu Ditch gate through WASP simulation. The simulation results show that after 4 hours of opening the Baozhu Ditch gate, at the river section (Ziyou Bridge) and downstream Longxin Bridge, the concentration of $\mathrm{NH}_{3}-\mathrm{N}$ increased from the background values of 8.53 and $6.35 \mathrm{mg} / \mathrm{L}$ to 12.57 and $9.17 \mathrm{mg} / \mathrm{L}$, respectively. $\mathrm{The}^{\mathrm{NH}_{3}-}$ $\mathrm{N}$ concentration of Ziyou Bridge was Simulated at $8.80 \mathrm{mg} / \mathrm{L}$ on the third day. The $\mathrm{NH}_{3}-\mathrm{N}$ concentration of Longxin Bridge was Simulated at $6.44 \mathrm{mg} / \mathrm{L}$ on the fifth day. The above results show that after opening the Baozhu Ditch gate, the water quality of $\mathrm{NH}_{3}-\mathrm{N}$ in the river was affected, and the usual concentration range was restored after least three days. Owing to the impact of tidal pushback of Love River, it should take five days for the downstream of Longxin Bridge to reach the usual level.
Table 3.3 WASP simulation of $\mathrm{NH}_{3}-\mathrm{N}$ changes in Love River after the gate of Baozhu Ditch is open for 4 hours.

\begin{tabular}{|l|l|l|}
\hline location & Ziyou Bridge & Longxin Bridge \\
\hline background values & $9.06 \mathrm{mg} / \mathrm{L}$ & $8.16 \mathrm{mg} / \mathrm{L}$ \\
\hline $4 \mathrm{hr}$ & $17.05 \mathrm{mg} / \mathrm{L}$ & $12.56 \mathrm{mg} / \mathrm{L}$ \\
\hline Day1 & $13.97 \mathrm{mg} / \mathrm{L}$ & $12.10 \mathrm{mg} / \mathrm{L}$ \\
\hline Day2 & $10.15 \mathrm{mg} / \mathrm{L}$ & $10.45 \mathrm{mg} / \mathrm{L}$ \\
\hline Day3 & $9.34 \mathrm{mg} / \mathrm{L}$ & $8.99 \mathrm{mg} / \mathrm{L}$ \\
\hline Day4 & $8.98 \mathrm{mg} / \mathrm{L}$ & $8.79 \mathrm{mg} / \mathrm{L}$ \\
\hline Day5 & $8.89 \mathrm{mg} / \mathrm{L}$ & $8.15 \mathrm{mg} / \mathrm{L}$ \\
\hline Day6 & $8.85 \mathrm{mg} / \mathrm{L}$ & $8.02 \mathrm{mg} / \mathrm{L}$ \\
\hline Day7 & $8.80 \mathrm{mg} / \mathrm{L}$ & $7.83 \mathrm{mg} / \mathrm{L}$ \\
\hline
\end{tabular}

Table 3.4 shows the changes of BOD concentration in Love River after 4 hours of opening and closure of the Baozhu Ditch gate through WASP simulation. The simulation results show that after 4 hours of opening the Baozhu Ditch gate, at the river section (Ziyou Bridge) and downstream Longxin Bridge increased from the background values of 9.06 and $8.16 \mathrm{mg} / \mathrm{L}$ to 17.05 and $12.56 \mathrm{mg} / \mathrm{L}$, respectively. The BOD concentration of Ziyou Bridge was Simulated at $9.34 \mathrm{mg} / \mathrm{L}$ on the third day. The BOD concentration of Longxin Bridge was Simulated at $8.15 \mathrm{mg} / \mathrm{L}$ on the fifth day. The above results show that after opening the Baozhu Ditch gate, the water quality of BOD in the river was affected, and the usual concentration range was restored after least three days. Owing to the impact of tidal push-back of Love River, it should take four days for the downstream of Longxin Bridge to reach the usual level.

Table 3.4 WASP simulation of BOD changes in Love River after the gate of Baozhu Ditch is open for 4 hours

\begin{tabular}{|l|l|l|}
\hline location & Ziyou Bridge & Longxin Bridge \\
\hline background values & $8.53 \mathrm{mg} / \mathrm{L}$ & $6.35 \mathrm{mg} / \mathrm{L}$ \\
\hline $4 \mathrm{hr}$ & $12.57 \mathrm{mg} / \mathrm{L}$ & $9.17 \mathrm{mg} / \mathrm{L}$ \\
\hline Day1 & $11.19 \mathrm{mg} / \mathrm{L}$ & $8.97 \mathrm{mg} / \mathrm{L}$ \\
\hline Day2 & $9.33 \mathrm{mg} / \mathrm{L}$ & $8.15 \mathrm{mg} / \mathrm{L}$ \\
\hline Day3 & $8.80 \mathrm{mg} / \mathrm{L}$ & $7.35 \mathrm{mg} / \mathrm{L}$ \\
\hline Day4 & $8.52 \mathrm{mg} / \mathrm{L}$ & $6.79 \mathrm{mg} / \mathrm{L}$ \\
\hline Day5 & $8.43 \mathrm{mg} / \mathrm{L}$ & $6.44 \mathrm{mg} / \mathrm{L}$ \\
\hline Day6 & $8.37 \mathrm{mg} / \mathrm{L}$ & $6.34 \mathrm{mg} / \mathrm{L}$ \\
\hline Day7 & $8.29 \mathrm{mg} / \mathrm{L}$ & $6.33 \mathrm{mg} / \mathrm{L}$ \\
\hline
\end{tabular}

\section{Conclusions}

(1) According to the data of Love River from 2011 to 2014, the simulated and measured results of BOD and $\mathrm{NH}_{3}-\mathrm{N}$ with the changes of river distance in different seasons show that there is a gap between the simulated and measured values of BOD from the downstream boundary. The main cause is that the $\mathrm{BOD}$ and $\mathrm{NH}_{3}-\mathrm{N}$ pollution loads discharged by K-Trunk and Baozhu Ditch are much higher than those in other tributaries. The simulation trend of the overall model obviously changes, which is a reasonable result after comparing with the actual pollutant loads.

(2) The study confirms that the water quality of the river's tributaries is seriously polluted. The WASP 
simulation confirms that the impact of ammonia nitrogen in Baozhu Ditch is greater than that of K-Trunk, while their BOD is similar; but the total amount of water in Baozhu Ditch is large. As a whole, the opening and closure of interception systems at Baozhu Ditch and KTrunk are bound to have a considerable impact on the water quality of Love River.

(3) Through a simulation of the impacts of opening the gates at Baozhu Ditch and K-Trunk for 4, 12, and 24 hours on $\mathrm{NH}_{3}-\mathrm{N}$ and BOD at the downstream, it is found that when the gate of Baozhu Ditch is open for 4 hours and the gate of K-Trunk is open for 24 hours, the simulated value is most similar to the highest value collected, and the contents of BOD and $\mathrm{NH}_{3}-\mathrm{N}$ are consistent with the simulation results. This proves that the closure of the interception system will affect Love River.

(4) The model herein is adopted to assess the selfpurification capacity of the river. The results show that when the Baozhu Ditch gate is opened, the $\mathrm{NH}_{3}-\mathrm{N}$ and BOD contents in the water of Love River will increase. Moreover, it takes at least five days for the river to return to its original water quality status after closure.

\section{References}

1. B.Z. Yang, Department of Civil Engineering, National Taiwan University,Taipei (2005).

2. C.H. Lin, National United University (2006).

3. Y.Y. Tasi, National Sun Yat-Sen University (2011).

4. P.G. Tang, National Pingtung University of Science and Technology (2013).

5. C.H. Yen, K.F. Chen, Y.T. Shen, C.C. Lin, J.J. Horng, Clean-Soil Air Water (2012).

6. Y.C. Lai, Y.T. Tu, C.P. Yang, R.Y. Surampalli, C.M. Kao, J. Hydrol. 478, 89 (2013).

7. Y.C. Lai, C.M. Kao, R.Y. Surampalli, Wat. Environ. Res. 82(11), 2205 (2010).

8. Y.C. Lai, C.P. Yang, C.Y. Hsieh, C.Y. Wu, C.M. Kao, J. Hydrol. 409, 583 (2011).

9. C.P. Yang, P.C. Chiang, E.E. Chang, T.F. Lin, C.M. Kao, Desalin water treat. 51, 6808 (2013). 